International Journal of Life Sciences
Available online at http://sciencescholar.us/journal/index.php/ijls
Vol. 3 No. 3, December 2019, pages: $32 \sim 40$
e-ISSN: 2550-6986, p-ISSN: 2550-6994
https://doi.org/10.29332/ijls.v3n3.360

\title{
Direct Organogenesis in Vitro Propagation of Local Balinese Banana with Thidiazuron
}

\author{
(1) corshatak

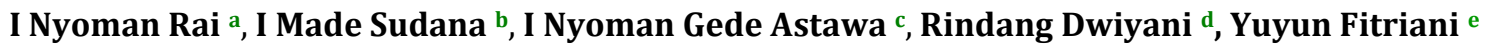 \\ Article history: Received 18 May 2019, Accepted: 31 August 2019, Published: 23 November 2019
}

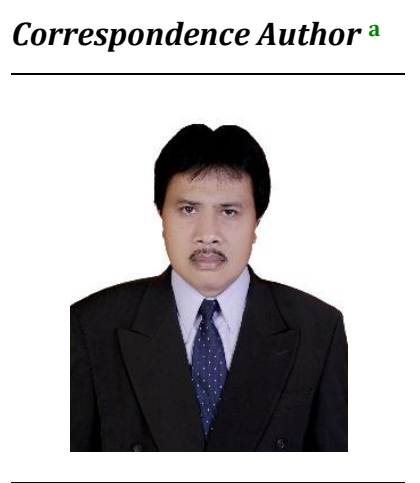

Keywords

in vitro;

local Balinese banana;

organogenesis;

propagation;

thidiazuron;

\begin{abstract}
Bali's community needs for bananas are very high, but cannot be fulfilled from the production of bananas in Bali. The main problem for banana cultivation in Bali is the difficulty of getting seeds. Direct organogenesis is offered to overcome this problem. The objective of the research was to study direct organogenesis on in vitro propagation of local Balinese banana with Thidiazuron. The research was carried out at Tissue Culture Laboratory, Faculty of Agriculture, Udayana University, Denpasar, Bali. The experiment was laid out in a completely randomized design with five treatments of thidiazuron concentration, i.e. $0 ; 0.5 ; 1.0 ; 1.5$, and $2.0 \mathrm{ppm}$. Each treatment was replicated 5 times. The Murashige \& Skoog medium added with coconut water and extract of bamboo shoots was used as a basic medium. The local Balinese bananas named Saba and Susu were used as source of planting materials. Explants were taken from shoot tips of suckers of newly growing plants. The results showed that the best treatment for both Saba and Susu, was $1 \mathrm{ppm}$ of thidiazuron, as indicated by the highest number of plantlets produced, the number of shoots and plant height.
\end{abstract}

e-ISSN: 2550-6986, p-ISSN: 2550-6994@C Copyright 2019. The Author. SS Journals Published by Universidad Técnica de Manabí. This is an open-access article under the CC BY-SA 4.0 license (https://creativecommons.org/licenses/by-sa/4.0/) All rights reserved.

\section{Contents}

Abstract

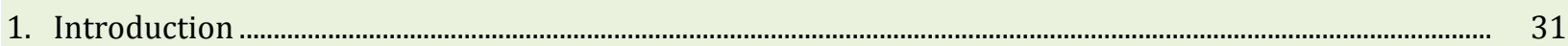

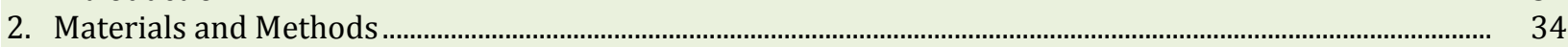

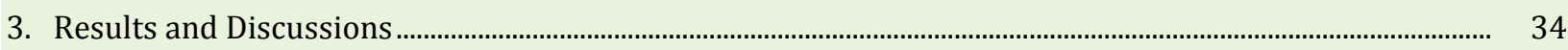

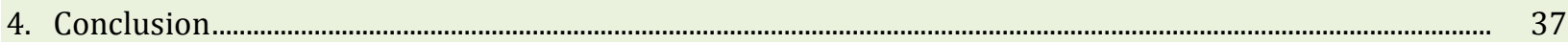

a Udayana University, Denpasar, Indonesia

b Udayana University, Denpasar, Indonesia

c Udayana University, Denpasar, Indonesia

d Udayana University, Denpasar, Indonesia

e Udayana University, Denpasar, Indonesia 


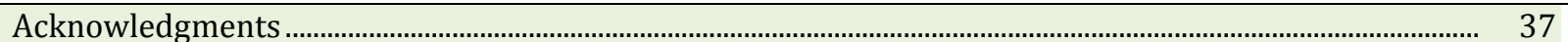

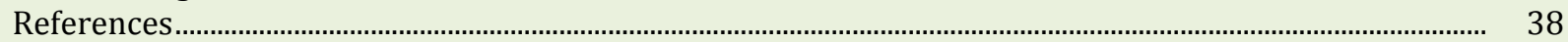

Biography of Authors .............................................................................................................................. 40

\section{Introduction}

Indonesia is one of the countries with the highest diversity of bananas in the world (Convention on Biological Diversity, 2017). According to Prabawati et al., (2008), in Indonesia at least there are 230 types of bananas, spread throughout the province so that almost all regions in Indonesia produce bananas. Besides having a high diversity, production volume of Indonesian banana including in the sixth ranks position in the world, but only ranks $60^{\text {th }}$ in global banana exports (FAO, 2018).

Bali with its unique geographical conditions also has a high diversity of bananas. Rai et al., (2017), found 43 types of local Balinese bananas (biu) in nine districts/cities that were sporadically distributed. Local Balinese bananas are all types of bananas that are already commonly developed and cultivated in Bali according to the definition of Article 1 Paragraph 6 of the Province of Bali Regulation Number 3 of 2013 concerning Protection of Local Fruits.

Bananas play an important role in the lives of Balinese people. Almost all parts of banana plants in Bali are beneficial. In general the use of bananas by the Balinese people is divided into five categories, i.e. as processed/cooked (for cooking), dessert, traditional ritual materials, culture and religious ceremonies, decoration materials (ornament), and for others use such as medicine materials, raw materials of household industry, animal feed, food packaging, and others. Based on Local User Value Index (LUVI) calculated according to the method of Sheil et al., (2003); Rai et al., (2018a); Jain et al., 2017, obtained that from 43 types of local bananas, 7 types as the most widely used were biu Kayu, biu Susu, biu Mas, biu Lumut, biu Buluh, biu Saba, dan biu Batu.

The high demand for bananas in Bali exceeds the production capacity of Balinese farmers causing many bananas to be imported from outside the region. Therefore, local banana germplasm of Bali with diverse uses needs to be maintained to save from extinction as well as to reduce Bali's dependence on banana supply from other regions. This effort is not easy, one of the main obstacles is the difficulty of getting enough seed with adequate quality. Rai et al., (2018b), stated that from the experience in collaboration with Gianyar Regency Government in developing of 43 types' local bananas into botanical gardens germplasm in 2018, there was no suppliers or traders that can provide the seed which was needed, so the team must make and propagate their own seed. This shows that the propagation of local banana seedling in Bali is very necessary.

Propagation of banana seeds can be done with tissue culture techniques. This method has been carried out in many countries, including Indonesia, even on a very commercial scale, for example for Cavendish. But according to Israeli et al., (1995) and Husaini et al., (2011), multiplication of banana breeding is genetically specific (genotypic dependent) so that different responses can occur in the multiplication of bananas from the same genotype with the same propagation material. The existence of the genotypic dependent is a strong reason that the local Balinese banana propagation research to find the right propagation technology with tissue culture techniques still needs to be done.

Propagation by tissue culture will offer a great opportunity to produce large numbers of seeds in a relatively short time. In addition, tissue culture can also maintain superior parent properties and can produce fungi-free, bacterial, viral and pest-free seed (Bhojwani \& Razdan, 1996; Prabhuling \& Sathyanarayana, 2017; Kishor et al., 2017; Latunra et al., 2017; Suiraoka et al., 2017). Through tissue culture techniques new individual plant will be obtained that is genetically the same as parent (Dwiyani, 2015; Astiari et al., 2018), so propagation by tissue culture techniques is not only beneficial because it is able to produce large numbers of seed in a relatively short time, but also very beneficial to save resources genetics of local Balinese bananas.

Success in vitro propagation is greatly influenced by the composition of the planting media. The growing media consists of macronutrients, micronutrients, vitamins, carbon sources, and various kinds of plant growth regulators/PGR, both synthetic and natural from the auxin and cytokine groups (Eriansyah et al., 2014). PGR in tissue culture is used to regenerate explants into complete plants. Interactions between PGR used in culture media will determine the direction of development of the explants (Bhojwani \& Razdan, 1996; Linda, 2018). PGR of auxin group influences cell development and initiates root formation, whereas PGR of cytokines group

Rai, I. N., Sudana, I. M., Astawa, I. N. G., Dwiyani, R., \& Fitriani, Y. (2019). Direct organogenesis in vitro propagation of local balinese banana with thidiazuron. International Journal of Life Sciences, 3(3), 32-40.

https://doi.org/10.29332/ijls.v3n3.360 
influences cell division and initiates shoot bud formation (Rivai \& Helmanto, 2015; Latunra et al., 2017; Kishor et al., 2017; Ogu \& Orjiakor, 2017).

Method of in vitro propagation of bananas can be done by direct or indirect organogenesis induction. The direct method of organogenesis induction is inducing and grows organs directly from explants in culture media containing high cytokine hormones or can also grow them on media with $\mathrm{GA}_{3}$. In this research was tested the effect of Thidiazuron (N-phenyl-N'-1,2,3-thiadiazol-5-ylurea) concentration for direct organogenesis induction. Based on the description above, this research aimed to study different effects of Thidiazuron concentration on direct organogenesis on in vitro propagation of local Balinese bananas.

\section{Materials and Methods}

The research was carried out at The Tissue Culture Laboratory, Faculty of Agriculture, Udayana University, Denpasar. The experiment was laid out as a completely randomized design (CRD), with five treatments of thidiazuron (TDZ) concentration, i.e. 0 ppm $\left(\mathrm{Y}_{0}\right), 0.5 \mathrm{ppm}\left(\mathrm{Y}_{1}\right), 1.0 \mathrm{ppm}\left(\mathrm{Y}_{2}\right), 1.5 \mathrm{ppm}\left(\mathrm{Y}_{3}\right)$, and $2.0 \mathrm{ppm}\left(\mathrm{Y}_{4}\right)$. Each treatment was replicated 5 times. The Murashige \& Skoog (MS) medium was used as a basic medium. Two grams per liter of polyvinyl phyrrolidone (PVP), $30 \mathrm{gL}^{-1}$ of glucose, and $2 \mathrm{gL}^{-1}$ of active charcoal were incorporated into the medium. The medium then was solidified with two grams of gellan gum (GG) and sterilized for 30 minutes at $121^{\circ} \mathrm{C}$ of autoclaving The local Balinese bananas named Saba and Susu were used as planting material.

Explants were taken from shoot tip of suckers of newly growing plants. The explants were sterilized following the procedures. Suckers were taken from the field and then were peeled by removing one to two outermost layers. The peeled suckers then were washed in the tap water using detergent solution (10\%) and rinsed with sterilized water twice (while shaking) with five minutes rinse each. Those suckers were then immersed in a 20\% solution of Dithane M-45 (fungicide) for 60 minutes and then rinsed with sterilized water twice for 10 minutes each. After that those suckers were immersed with $20 \%$ sodium hypochlorite solution for 30 minutes, rinsed twice and then put in the laminar. In the laminar, those peeled suckers were immersed again with $15 \%$ sodium hypochlorite solution for 10 minutes, rinsed with sterilized distilled water three times and then put in the sterilized filter paper in the petri dish. The layers of those suckers were then again peeled until remaining the innermost layer. Finally, the peeled sucker was cut into 1 to $2 \mathrm{~cm}$ in size of explants, then dipped into the filter-sterilized of ascorbic acid and then cultured in the medium.

The observation was done for the variables of the percentage shoot-forming explants, the number of shoots per plantlet, the number of leaves per plantlet, and the number of roots per plantlet, root length per plantlet, and the percentage of successful acclimation.

\section{Results and Discussions}

The results showed that the best shoot growth, both for Saba and Susu, was obtained at 1 ppm $\left(\mathrm{Y}_{2}\right)$ Thidiazuron concentration, mainly indicated by the percentage of explants forming shoots, the average number of shoots per plantlet, and percentage of acclimation success (Table 1). In Saba banana, the number of explants that succeeded in forming shoots at concentration of $0.5\left(\mathrm{Y}_{1}\right), 1.0\left(\mathrm{Y}_{2}\right)$ and $1.5 \mathrm{ppm}\left(\mathrm{Y}_{3}\right)$ were 20, 64, and $48 \%$, respectively, while in Susu bananas were slightly lower that was only 16, 52 and 44\%. At concentration of $0\left(\mathrm{Y}_{0}\right)$ and $2.0 \mathrm{ppm}\left(\mathrm{Y}_{4}\right)$, both on Saba and Susu, the explants died and dried up so none of them succeeded in forming shoots and the average number of shoots, number of leaves, number of roots, root length and acclimatization success were not observed in observations at 8 weeks after planting/WAP (Table 1). 
Table 1

Effect of TDZ concentrations on various variables on the propagation of Saba and Susu bananas with tissue culture

\begin{tabular}{|c|c|c|c|c|c|}
\hline Variables & $\begin{array}{l}0 \mathrm{ppm} \\
\mathrm{TDZ}\left(\mathrm{Y}_{0}\right)\end{array}$ & $\begin{array}{l}0,5 \mathrm{ppm} \\
\left.\text { TDZ (Y } \mathrm{Y}_{1}\right)\end{array}$ & $\begin{array}{l}1,0 \mathrm{ppm} \\
\text { TDZ }\left(\mathrm{Y}_{2}\right)\end{array}$ & $\begin{array}{l}1,5 \mathrm{ppm} \\
\mathrm{TDZ}\left(\mathrm{Y}_{3}\right)\end{array}$ & $\begin{array}{l}2,0 \mathrm{ppm} \\
\mathrm{TDZ}\left(\mathrm{Y}_{4}\right)\end{array}$ \\
\hline \multicolumn{6}{|l|}{ Saba Banana } \\
\hline $\begin{array}{l}\text { 1. Percentage of explants forming shoots } \\
(\%)\end{array}$ & 0 & 20 & 64 & 48 & 0 \\
\hline $\begin{array}{l}\text { 2. The average number of shoots per } \\
\text { plantlet at } 10 \mathrm{WAP} \text {. }\end{array}$ & - & 1,40 & 1,75 & 1,16 & - \\
\hline $\begin{array}{l}\text { 3. The average number of leaves per } \\
\text { plantlet at } 10 \mathrm{WAP}\end{array}$ & - & 3,52 & 4,18 & 4,01 & - \\
\hline $\begin{array}{l}\text { 4. The average number of roots per } \\
\text { plantlet at } 10 \text { WAP. }\end{array}$ & - & 4,67 & 5,32 & 3,68 & - \\
\hline $\begin{array}{l}\text { 5. Average root length per plantlet at } 10 \\
\text { WAP. }\end{array}$ & - & 6,63 & 7,82 & 5,70 & - \\
\hline 6. Percentage of acclimation success (\%) & - & 0 & 93,75 & 0 & - \\
\hline Susu Banana & & & & & \\
\hline $\begin{array}{l}\text { 1. Percentage of explants forming shoots } \\
(\%)\end{array}$ & 0 & 16 & 52 & 44 & 0 \\
\hline $\begin{array}{l}\text { 2. The average number of shoots per } \\
\text { plantlet at } 10 \mathrm{WAP} \text {. }\end{array}$ & - & 1,66 & 1,46 & 1,36 & - \\
\hline $\begin{array}{l}\text { 3. The average number of leaves per } \\
\text { plantlet at } 10 \mathrm{WAP}\end{array}$ & - & 3,33 & 3,38 & 3,09 & - \\
\hline $\begin{array}{l}\text { 4. The average number of roots per } \\
\text { plantlet at } 10 \text { WAP. }\end{array}$ & - & 3,33 & 3,46 & 2,09 & - \\
\hline 5. Average root length per plantlet at 10 & & & & & \\
\hline WAP. & - & 4,18 & 4,73 & 3,24 & - \\
\hline 6. Percentage of acclimation success (\%) & - & 0 & 69,23 & 0 & - \\
\hline
\end{tabular}

Note: $(-)$ was not observed

Besides giving the highest percentage of explants that succeeded in forming shoots, the concentration of 1,0 ppm TDZ $\left(\mathrm{Y}_{2}\right)$ also provided the highest number of shoots, number of leaves, number of roots, root length and acclimation success, both on Saba and Susu banana (Figure 1 and 2). In Saba banana, the percentage of acclimatization reached $93.75 \%$ while in Susu banana was only $69.23 \%$. These data indicate that the $1.0 \mathrm{ppm}$ TDZ concentration was the best concentration in the growing medium in the propagation of Saba and Susu banana. Chin-Yi-Lu (1993), stated that Thidiazuron ( $N$-phenyl- $N$ '-1,2,3-thiadiazol-5-ylurea) is growth regulator to have cytokines activity and has been used successfully in vitro to induce shoot formation and to promote axillaries shoot proliferation. Low concentrations of Thidiazuron (1,0-2,0 ppm) was found effective for in vitro propagation of Rauvolfia tetraphylla L. (Faisal et al., 2005); Ephedra gerardiana (Sharma et al., 2012), Rauvolfia serpentine (Alatar, 2015), swettpotato (Masekesa et al., 2016), and Phalaenopsis amabilis (L.) Blume Orchid (Mose et al., 2017), but high concentration ( $>2,5 \mathrm{ppm}$ ) or prolonged exposure to thidiazuron should be avoided, as this may cause hyperhydricity, drying up the explants, growing abnormal shoot morphology, inhibit shoot elongation, or problems in rooting (Chin-Yi-Lu, 1993; Alatar, 2015, Masekesa et al., 2016). At this research, concentration of TDZ more than 1,00 ppm was not good for acclimatization, even on $2,0 \mathrm{ppm}$ all explants did not grow shoot. These conditions may result in the formation of plantlets with abnormal morphology, anatomy, and physiology, which lead to the death of plantlets.

Although the concentration of 1 ppm TDZ $\left(\mathrm{Y}_{2}\right)$ was able to give the highest percentage of explants developing into shoots and the highest acclimation success, the weakness was that the number of shoots per culture bottle produced was very low, ranging from 1.16 to 1.75 shoots at Saba and 1.36 up to 1.66 shots at Susu. The low number of shoots per culture bottle produced in terms of multiplication of shoots is not good because for mass propagation will require a lot of explants (Ali \& Mehmood, 2017; Opabode, 2017; Singh,

Rai, I. N., Sudana, I. M., Astawa, I. N. G., Dwiyani, R., \& Fitriani, Y. (2019). Direct organogenesis in vitro propagation of local balinese banana with thidiazuron. International Journal of Life Sciences, 3(3), 32-40. https://doi.org/10.29332/ijls.v3n3.360 
2018). Nuragira et al., (2015), also stated that because of low rate of multiplication of In-vitro plantlets, it takes many years to generate large quantities of seed to meet the demand of the seed potato industry in Uganda. Therefore, it is necessary to further investigate how to increment the number of shoots per explants of in vitro propagation of local Balinese banana. Some efforts possible to try, such as use of higher concentrations of GA3 supplemented with other phytohormones like BAP and NAA, and vitamins (Muhammad et al., 2004, Deo \& Pradhan, 2017), evaluate each subculture (Tumuhimbise \& Talengera, 2018), use different source of rhizome/corm explants (Ikram-ul-Haq \& Dahot, 2007), and use different ratio of auxin and cytokinine on media culture (Ngomuo et al., 2013; Lohidas \& Sujin, 2015; Latunra et al., 2017; Kishor et al., 2017; Linda, 2018). However, based on the results of this study, it is temporarily advisable to produce Saba and Susu bananas with tissue culture in order to use TDZ concentration in the planting medium at $1.0 \mathrm{ppm}$ concentration.

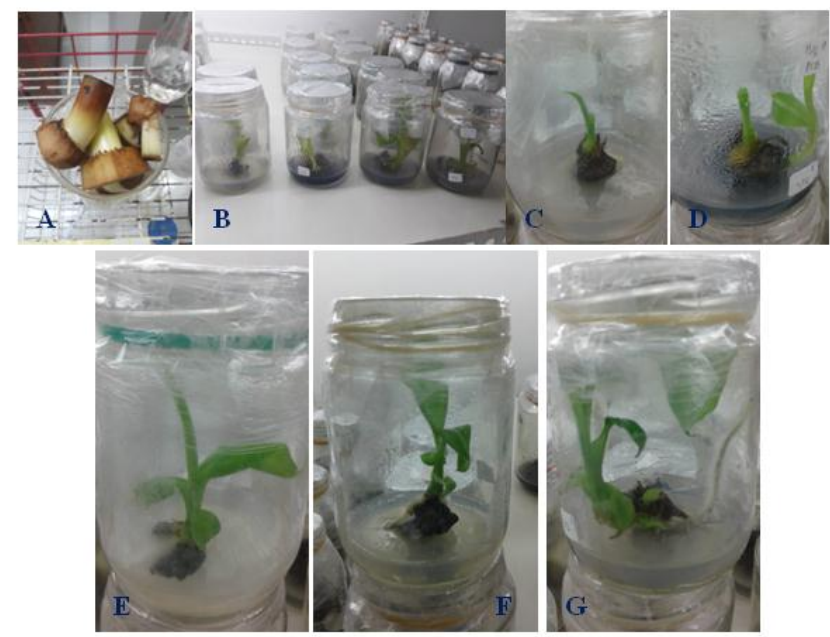

Figure 1. Shoot tip Saba explants (taken from one-month rhizome aged) (A), appearance of Saba plantlets aged 2 WAP (B), 4 WAP (C), 6 WAP (C and D), and 8 WAP (E, F, and G).

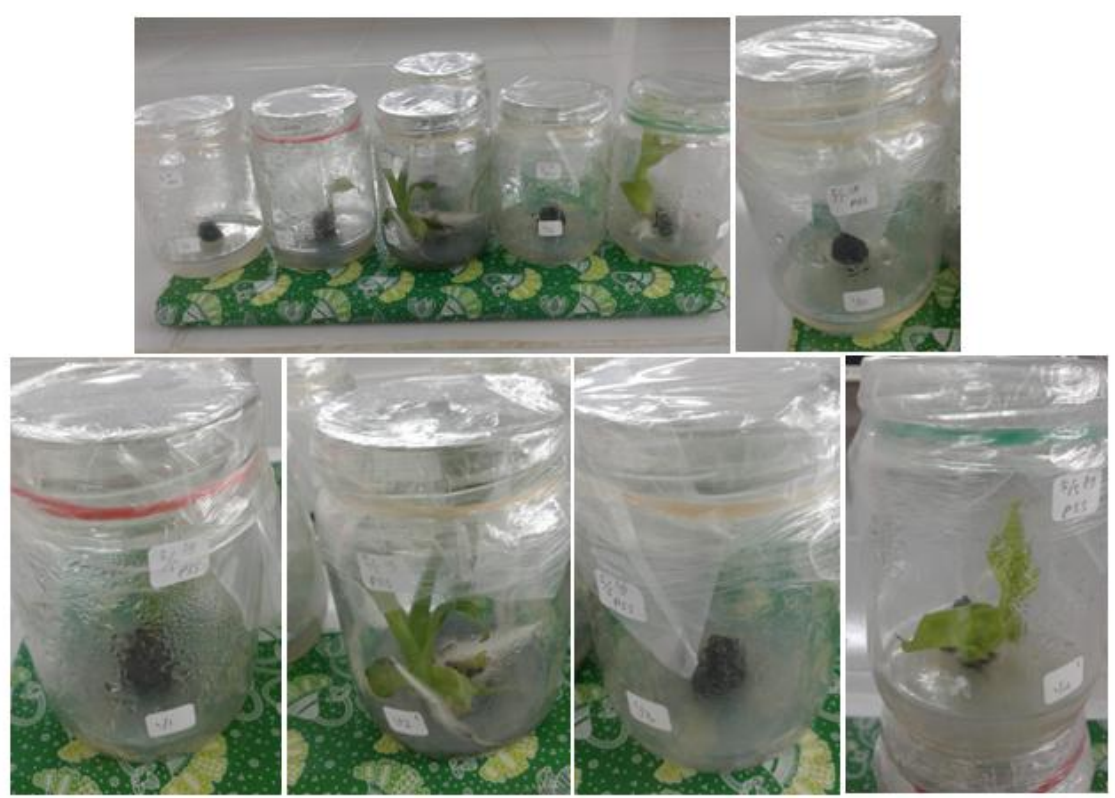

Figure 2. The appearance of Susu plantlets at Y0, Y1, Y2, Y3, and Y4 of TDZ concentration (upper) at 8 WAP, and the best concentration is at $\mathrm{Y} 2=1 \mathrm{ppm}$ TDZ (below, number 2 from the left). 


\section{Conclusion}

The results showed that the best shoot growth, both for Saba and Susu, was obtained at $1 \mathrm{ppm}$ Thidiazuron concentration, mainly indicated by the number of plantlets produced and success in seedling acclimatization. At the $Y_{2}$ concentration, besides giving the highest percentage of explants that succeeded in developing into shoots, it also provided the highest number of shoots, number of leaves, number of roots, root length and acclimation success, both on Saba and Susu banana. Although TDZ of 1 ppm concentration was able to give the highest percentage of explants developing into shoots and the highest acclimation success, the weakness was that the number of shoots per culture bottle produced was very low, ranging from 1.16 to 1.75 shoots at Saba and 1.36 up to 1.66 shoots on Susu.

\section{Acknowledgments}

The authors would like to thank the reviewer for their consideration of the further process of the present paper. Thanks to the editor of IJLS for the valuable support, time as well as advice.

Rai, I. N., Sudana, I. M., Astawa, I. N. G., Dwiyani, R., \& Fitriani, Y. (2019). Direct organogenesis in vitro propagation of local balinese banana with thidiazuron. International Journal of Life Sciences, 3(3), 32-40. https://doi.org/10.29332/ijls.v3n3.360 


\section{References}

Alatar, A. A. (2015). Thidiazuron induced efficient in vitro multiplication and ex vitro conservation of Rauvolfia serpentina-a potent antihypertensive drug producing plant. Biotechnology \& Biotechnological Equipment, 29(3), 489-497. https://doi.org/10.1080/13102818.2015.1017535

Ali, S., \& Mehmood, S. (2017). Micro Propagation of cv. Basrai (Banana) Using Growth Hormones. J Hortic, 4(195), 2376-0354. https://doi.org/10.4172/2376-0354.1000195

Astiari, N. K. A., Kartini, L., Sulistiawati, N. P. A., \& Rai, I. N. (2018). Efforts to produce Siamese citrus fruit out of season and fruit quality improvement through application of potassium nitrate and agrodyke fertilizer. International Journal of Life Sciences, 2(3), 48-58. https://doi.org/10.29332/ijls.v2n3.206

Bandita, D., \& Bikram, P. (2017). Effects of plant growth hormones on shoot proliferation of Musa paradisiaca cv. BANTAL. International Journal of Plant Sciences (Muzaffarnagar), 12(2), 135-138. http://dx.doi.org/10.15740/has/ijps/12.2/135-138

Bhojwani, S. S., \& Razdan, M. K. (1996). Plant tissue culture, theory and practices. A revised edition. Studies in plant science, 5.

Convention on Biological Diversity. (2017). Indonesia-Country Profile. https://www.cbd.int/countries/profile/default.shtml?country=id. Montreal, Canada. Accessed on 22/09/2017

Dahot, M. U. (2007). Micro-propagation efficiency in banana (Musa sp.) under different immersion systems. Pakistan journal of biological sciences: PJBS, 10(5), 726-733. https://doi.org/10.3923/pjbs.2007.726.733

Dwiyani, R. (2015). Kultur Jaringan Tanaman. Pelawa Sari, Denpasar.

Eriansyah, M., Susiyanti, S., \& Putra, Y. (2018). Pengaruh Pemotongan Eksplan Dan Pemberian Beberapa Konsentrasi Air Kelapa Terhadap Pertumbuhan Dan Perkembangan Eksplan Pisang Ketan (Musa paradisiaca) Secara In Vitro. Agrologia, 3(1). http://dx.doi.org/10.30598/a.v3i1.260

Faisal, M., Ahmad, N., \& Anis, M. (2005). Shoot multiplication in Rauvolfia tetraphylla L. using thidiazuron. Plant Cell, Tissue and Organ Culture, 80(2), 187-190. https://doi.org/10.1007/s11240-0040567-X

FAO (Food and Agriculture Organization). 2018. Post-harvest management of banana for quality and safety assurance. Guidance for horticultural supply chain stakeholders. Food and Agriculture Organization of the United Nations (FAO). Viale delle Terme di Caracalla 00153 Rome, Italy. www.fao.org. 24p.

Husaini, A. M., Mercado, J. A., da Silva, J. A. T., \& Schaart, J. G. (2011). Review of factors affecting organogenesis, somatic embryogenesis and Agrobacterium tumefaciens-mediated transformation of strawberry. Genes, Genomes and Genomics (Special Issue I), 5, 1-11.

Israeli, Y., Lahav, E., \& Reuveni, O. (1995). In vitro culture of bananas. In Bananas and plantains (pp. 147-178). Springer, Dordrecht. https://doi.org/10.1007/978-94-011-0737-2_6

Jain, P., Jain, A., Singhai, R., \& Jain, S. (2017). Effect of bio-degradation and non degradable substances in environment. International Journal of Life Sciences, 1(1), 58-64. https://doi.org/10.21744/ijls.v1i1.24

Kishor, H., Abhijith, Y. C., \& Manjunatha, N. (2017). Micropropagation of native cultivars of Banana-A Critical Review. International Journal of Pure and Applied Bioscience, 5(5), 1559-1564.

Latunra, A. I. (2018). Induksi Kalus Pisang Barangan Merah Musa acuminata Colla dengan Kombinasi Hormon 2, 4-D dan Bap Secara In Vitro. Jurnal Ilmu Alam dan Lingkungan, 8(1).

Linda, R. Perbanyakan Tunas Pisang Cavendish (Musa acuminata L.) Secara In Vitro dengan Penambahan Naphthalene Acetic Acid (NAA) dan Air Kelapa. Protobiont, 7(1).

Lohidas, J., \& Sujin, D. (2015). Effect of growth hormones in the micro propagation of banana CV. Matti. Plant Archives, 15(1), 307-314.

Lu, C. Y. (1993). The use of thidiazuron in tissue culture. In Vitro Cellular \& Developmental Biology-Plant, 29(2), 92-96. https://doi.org/10.1007/BF02632259

Masekesa, T. R., Gasura, E., Ngadze, E., Icishahayo, D., Kujeke, G. T., Chidzwondo, F., \& Robertson, I. (2016). Efficacy of Zeatin, Kinetin and Thidiazuron in induction of adventitious root and shoot from petiole explants of sweetpotato cv. Brondal. South African Journal of Botany, 104, 1-5. https://doi.org/10.1016/j.sajb.2015.11.001 
Mose, W., Indrianto, A., Purwantoro, A., \& Semiarti, E. (2017). The influence of thidiazuron on direct somatic embryo formation from various types of explant in Phalaenopsis amabilis (L.) blume orchid. HAYATI Journal of Biosciences, 24(4), 201-205. https://doi.org/10.1016/j.hjb.2017.11.005

Muhammad, A., Hussain, I. Q. B. A. L., Naqvi, S. S., \& Rashid, H. (2004). Banana plantlet production through tissue culture. Pakistan Journal of Botany, 36(3), 617-620.

Ngomuo, M., Mneney, E., \& Ndakidemi, P. (2013). The effects of auxins and cytokinin on growth and development of (Musa sp.) var."Yangambi" explants in tissue culture. American Journal of Plant Sciences, 4(11), 2174. http://dx.doi.org/10.4236/ajps.2013.411269

Nuwagira, F., Mukasa, S. B., Wagoire, W. W., Namugga, P., Kashaija, I. N., \& Barekye, A. (2015). Determination of hormonal combination for increased multiplication of tissue culture potato plantlets. Uganda Journal of Agricultural Sciences, 16(1), 129-137. http://dx.doi.org/10.4314/ujas.v16i1.11

Ogu, G. I., \& Orjiakor, P. I. (2017). Microbiological and nutritional qualities of fermented melon seed shells. International Journal of Life Sciences, 1(2), 1-9. https://doi.org/10.21744/ijls.v1i2.27

Opabode, J. T. (2017). Sustainable mass production, improvement, and conservation of African indigenous vegetables: The role of plant tissue culture, a review. International Journal of Vegetable Science, 23(5), 438455. https://doi.org/10.1080/19315260.2017.1319006

Prabawati, S., Suyanti, S., \& Setyabudi, D. A. (2008). Teknologi Pascapanen dan Pengolahan Buah Pisang. In Balai Besar Penelitian dan Pengembangan Pascapanen Pertanian. Seminar Badan Litbang Pertanian. Departemen Pertanian. Bogor.

Prabhuling, G., \& Sathyanarayana, B. N. (2017). Optimization of explants density for tissue culture propagation of banana cv.'Grande Naine'. International Journal of Agricultural Sciences, 13(1), 71-76. https://doi.org/10.15740/HAS/IJAS/13.1/71-76

Rai, I N., I M. Sudana, I M. Sukewijaya, I N.G. Ustriyana, I D.P. Oka Suardi, G.N.A. Susanta Wirya, D.N. Nyana. (2018b). Pengembangan Aneka Jenis Pisang di Kabupaten Gianyar. Laporan Akhir Kerjasama Dinas Pertanian, Kabupaten Gianyar Dengan Tim Fakultas Pertanian Universitas Udayana, 56.

Rai, I. N., Dwivany, F. M., Sutanto, A., Meitha, K., Sukewijaya, I. M., \& Ustriyana, I. N. G. (2018). Biodiversity of Bali Banana (Musaceae) and its Usefulness. Hayati Journal of Biosciences, 25(2), 47. https://doi.org/10.4308/hjb.25.2.47

Rai, I.N., I.W. Nuarsa, I.G.N. Alit Susanta Wirya, I.N.G. Ustriyana, D.P. Oka Suardi, M. Sukewijaya, K. Wikantika, F.M. Dwivany, K. Meitha. (2017). Studi Biogeografi dan Biodiversity Pisang Bali. Laporan Akhir Kegiatan Penelitian Bali International Research Center For Banana (BIRCB), 151.

Rivai, R. R., \& Helmanto, H. E. N. D. R. A. (2015). Induksi kalus Crhysanthemum indicum untuk meningkatkan keragaman genetic dari sel somatic. pros sem nas masy biodiv indon, 1(1), 167-170.

Sharma, V., Gupta, S. K., \& Dhiman, M. (2012). Regeneration of plants from nodal and internodal segment cultures of Ephedra gerardiana using thidiazuron. Plant Tissue Culture and Biotechnology, 22(2), 153-161. https://doi.org/10.3329/ptcb.v22i2.14205

Sheil, D., Puri, R. K., Basuki, I., van Heist, M., Wan, M., Liswanti, N., ... \& Angi, E. M. (2002). Exploring biological diversity, environment, and local people's perspectives in forest landscapes: Methods for a multidisciplinary landscape assessment. CIFOR.

Singh, C. R. (2018). Review on Problems and its Remedy in Plant Tissue Culture. Asian Journal of Biological Sciences, 11, 165-172. https://doi.org/10.3923/ajbs.2018

Suiraoka, I. P., Duarsa, D. P. P., Wirawan, I. D. N., \& Bakta, I. M. (2017). Perception of parents, teachers, and nutritionist on childhood obesity and barriers to healthy behavior: a phenomenological study. International Journal of Health Sciences, 1(2), 1-11. https://doi.org/10.21744/ijhs.v1i2.25

Tumuhimbise, R., \& Talengera, D. (2018). Improved Propagation Techniques to Enhance the Productivity of Banana (Musa spp.). Open Agriculture, 3(1), 138-145. https://doi.org/10.1515/opag-2018-0014

Rai, I. N., Sudana, I. M., Astawa, I. N. G., Dwiyani, R., \& Fitriani, Y. (2019). Direct organogenesis in vitro propagation of local balinese banana with thidiazuron. International Journal of Life Sciences, 3(3), 32-40. 


\section{Biography of Authors}

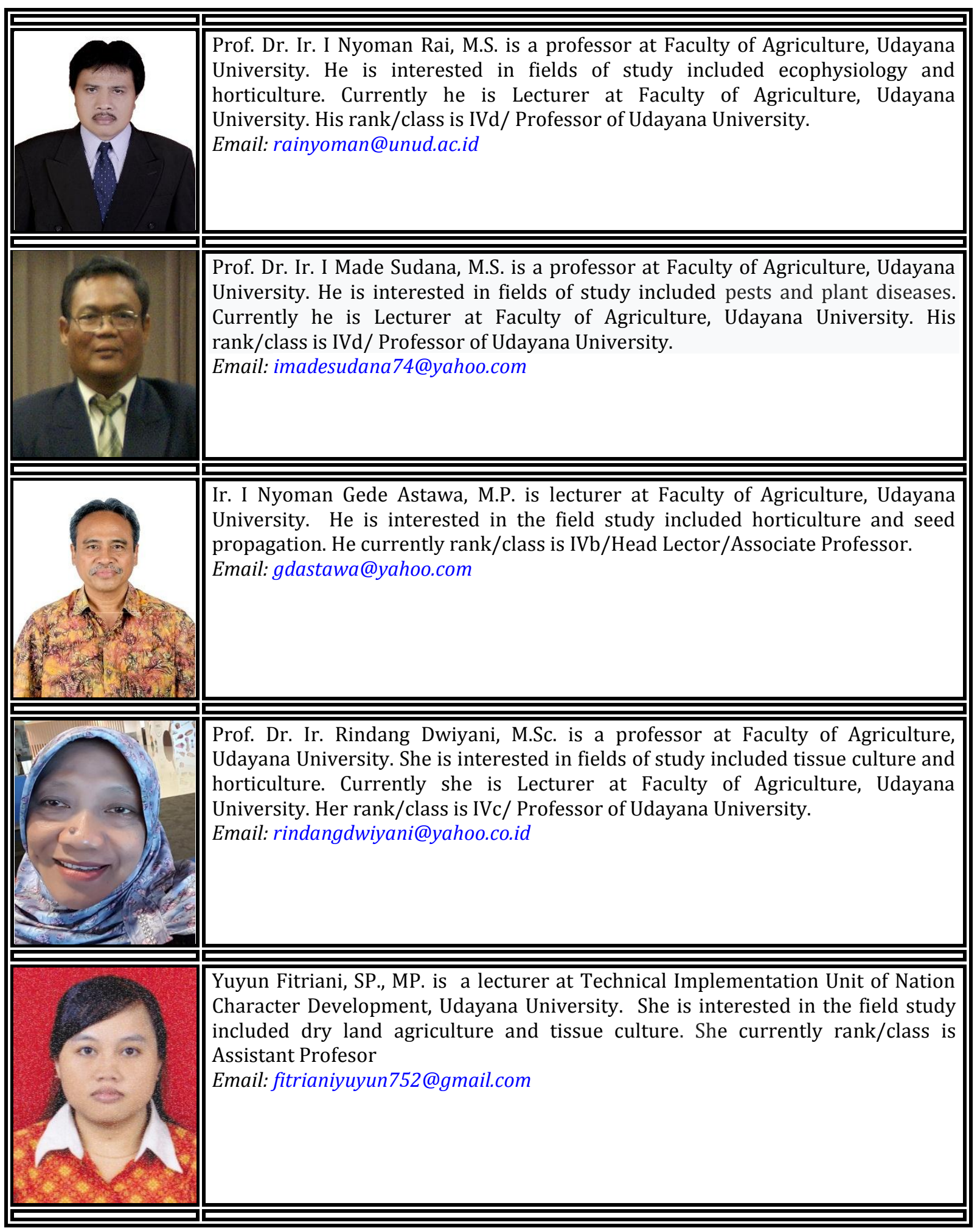

